\title{
Fox Ridge Energy and Educational Institute Project Development Report
}

\author{
For
}

Fox Ridge Wind farms, LLC

\section{MW Wind Farm}

\author{
Prepared by \\ Dale Osborn \\ Manager, Disgen Holdings, LLC \\ 12345 W Alameda Parkway, Suite 117 \\ Lakewood, CO 80228 \\ 303-531-5523
}

February 25, 2012

This material is based up on work supported by the Department of Energy under Award Number: De-FG36-06G086104 


\section{Project Description for Fox Ridge Wind Farms, LLC in Faith South Dakota}

Background: Faith is located in the northeast corner of Meade County South Dakota. The economy is agricultural; principally large cattle operations on sizeable ranches. As with most rural communities, the economy is under pressure with inadequate taxes and few economic development opportunities. In 2004 the single school house, constructed in the early 1900s, was condemned by the state fire marshal. The school serves K-12 and the school board had to locate, acquire and install modular trailers to support the children; population about 200. The state has not, and will not, provide funds to construct a new school as the political agenda is to focus on higher education. While a new school is being constructed, the Fox Ridge participants believe that the new school provides less than optimum services and facilities for the students. Fox Ridge Energy and Educational Institute has dedicated significant development funds and time in attempting to expand the public education system through the proceeds of this wind farm

A group of concerned citizens formed a 501C-3 tax exempt entity to examine methods of obtaining the capital to increase the capabilities of the school. In considering the resources available to the community, it was clear that the wind resource was excellent and with the continuing growth of the commercial wind industry, the group focused on wind energy as the primary opportunity to create a successful economic enterprise. The group lobbied for and received an ear mark from Congress in 2005 for \$500,000 to conduct feasibility and project development studies for the project. Matching funds of $\$ 125,000$ were required, which were raised locally along with an additional $\$ 700,000$. The community has provided additional support letters. Affected landowners also supported Fox Ridge. Three (3) fifty meter anemometers were installed in September 2005. Planning began for finance structures that would provide the targeted funds for the construction of a LEED certified school of about $\$ 20$ million. Further, the group has a goal of obtaining about $\$ 2$ million per year to support the operation of the school, including increased pay for teachers and restoration of educational programs which had to be reduced. The Faith School currently remains accredited through the use of distance learning for some of its core classes. The group has requested that Dale Osborn, Manager of Disgen Holdings, LLC (Disgen), an experienced wind energy developer, provide assistance in this opportunity. Osborn has agreed and is the author of this paper.

Project Area Description: The project area includes the rolling short grass prairie surrounding the Western Area Power Administration (Western) Maurine Substation. In the lower elevation areas, there are limited trees. There are no significant water accumulations in the area. The grass is grazed with cattle and sheep and some of the grass is harvested in bales for feed. Locating wind turbines in the project area would have limited impact on the current land use and its habitat. It is expected that the turbines and roads would occupy less than $4 \%$ of the land area. The area is bisected by US Highway 212 running east-west which is the major transportation corridor into Wyoming and Montana. This highway provides an excellent delivery route for the wind facility equipment. Below is a map of the proposed Project Area: 


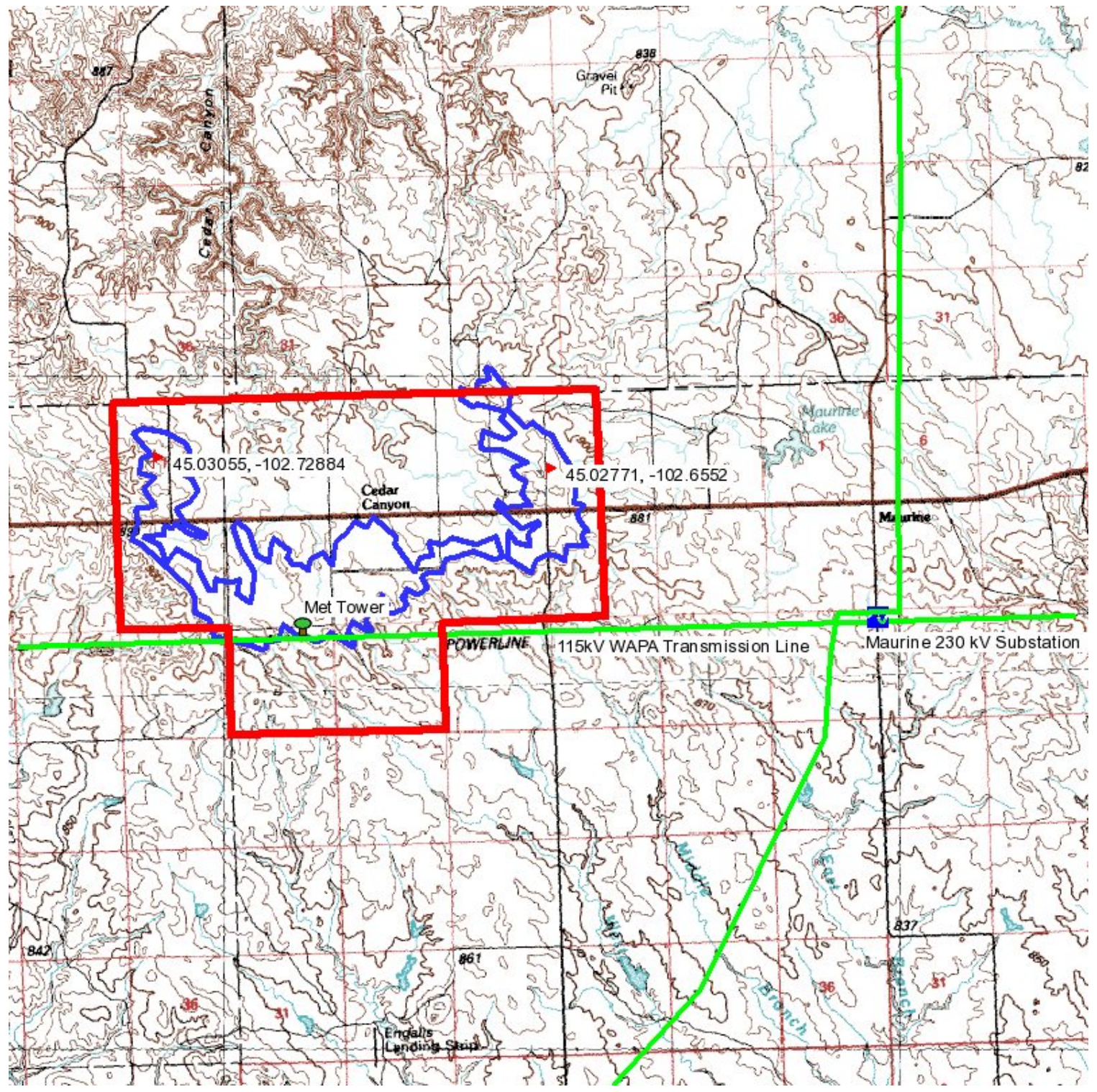

Project Size: For permitting and transmission capacity purposes, the project is planned for one hundred twenty (120MW). It is expected that the net capacity factor will be approximately forty six percent (46\%). This equates to about 50 average megawatts; or approximately 506,000 MWhr per year; approximately the annual equivalent of 56,000 homes. This project size also supports an Environmental Assessment (EA) from the Western Area Power Administration (Western). Western has confirmed in writing that the proposed 120MW would be permitted as an EA.

Wind Resource: Three 50m meteorological towers were installed under State of South Dakota anemometer loan program in February 2006 and data was retrieved for 16 
months. The locations of the towers were Haines, Olson and Ingalls and these towers have now been removed. The average annual wind speed at $50 \mathrm{~m}$ is 7.8 to 8.2 meters per second with the Olson location being the highest recorded data; a Class 6 Wind Resource. The dominate wind direction is from the northwest to southeast.

\begin{tabular}{|c|c|c|c|c|c|c|c|c|c|c|c|c|c|}
\hline & & & & M & AN $\mathrm{HO}$ & URLY V & WIND & SPEEDS & & & & & \\
\hline & & & & & & FOXRI & [DGE $S$ & & & & & & \\
\hline & & & & OL & SON 5 & OM WI & ND SP & EED & $\mathrm{CH} 1$ ) & (MPS) & & & \\
\hline & & & & & $\odot 2$ & $91 / 06$ & - 01 & $/ 31 / 07$ & & & & & \\
\hline Hour & Jan & Feb & Mar & Apr & May & Jun & Jul & Aug & Sep & oct & Nov & Dec & Mean \\
\hline--- & --- & ---- & --- & --- & --- & --- & --- & --- & --- & ---- & --- & - - - & +--- \\
\hline 01 & 12.4 & 6.3 & 9.2 & 9.6 & 8.1 & 7.9 & 8.5 & 7.5 & 8.5 & 7.8 & 8.6 & 8.4 & 8.5 \\
\hline$\odot 2$ & 11.7 & 5.6 & 9.2 & 9.4 & 7.9 & 7.8 & 7.9 & 7.4 & 8.4 & 8.3 & 8.5 & 8.8 & 8.4 \\
\hline 03 & 12.0 & 5.5 & 9.3 & 9.2 & 8.1 & 7.6 & 7.8 & 7.5 & 8.2 & 8.3 & 8.5 & 8.8 & 8.4 \\
\hline$\odot 4$ & 12.4 & $6 . \odot$ & 9.3 & 8.8 & 8.0 & 7.4 & 7.4 & 7.6 & 7.7 & 8.3 & 8.7 & 8.7 & 8.3 \\
\hline 05 & 12.1 & 5.8 & 9.6 & 8.4 & 8.1 & 7.4 & 7.5 & 7.2 & 7.4 & 8.6 & 8.8 & 8.4 & 8.2 \\
\hline 06 & 11.9 & 6.6 & 9.7 & 8.0 & 7.8 & 7.2 & 7.3 & 7.6 & 7.8 & 8.7 & 8.1 & 8.6 & 8.2 \\
\hline 07 & 12.0 & 7.2 & 9.2 & 7.9 & 7.1 & 6.7 & 6.6 & 6.7 & 7.8 & 8.6 & 7.7 & 8.1 & 7.8 \\
\hline$\odot 8$ & 11.9 & 6.9 & 8.7 & 7.5 & 7.2 & 6.6 & 6.2 & 6.5 & 7.6 & 8.1 & 7.6 & 8.3 & 7.5 \\
\hline$\odot 9$ & 11.8 & 7.5 & 8.4 & 7.8 & 7.3 & 6.3 & 6.3 & 6.7 & 7.1 & 8.0 & 7.1 & 8.4 & 7.4 \\
\hline 10 & 11.1 & 7.0 & 8.4 & 8.0 & 7.5 & 6.2 & 6.7 & 6.9 & 7.5 & 7.9 & 6.8 & 10.0 & 7.6 \\
\hline 11 & 12.1 & 6.5 & 8.5 & 7.8 & 7.5 & 6.4 & 6.8 & 7.5 & 7.5 & 7.8 & 7.2 & 10.6 & 7.7 \\
\hline 12 & 12.7 & 6.7 & 8.7 & 8.2 & 7.7 & 6.4 & 6.8 & 7.4 & 7.5 & 8.1 & 7.9 & 10.2 & 7.9 \\
\hline 13 & 14.0 & $7 . \odot$ & 8.8 & 8.2 & 8.0 & 6.4 & 6.8 & 7.1 & 7.8 & 8.2 & 7.7 & 10.3 & 8.0 \\
\hline 14 & 14.0 & 7.3 & 9.0 & 8.4 & 8.0 & 6.5 & 6.9 & 6.9 & 7.9 & 8.4 & 7.3 & 10.3 & 8.0 \\
\hline 15 & 13.9 & 7.7 & 9.1 & 8.6 & 8.4 & 6.2 & 6.6 & 6.8 & 7.9 & 8.6 & 7.3 & 9.8 & 8.0 \\
\hline 16 & 13.4 & 7.9 & 9.0 & 8.4 & 8.1 & 6.5 & 6.3 & 7.5 & 8.1 & 8.2 & 6.7 & 9.0 & 7.9 \\
\hline 17 & 11.4 & 7.8 & 8.6 & 8.4 & 8.3 & 6.6 & 6.7 & 7.6 & 7.6 & 8.0 & 6.8 & 9.0 & 7.8 \\
\hline 18 & 11.9 & 8.3 & 8.5 & 8.6 & 8.3 & 6.9 & 6.8 & 8.0 & 7.5 & 8.3 & 7.6 & 9.5 & 8.1 \\
\hline 19 & 11.1 & 9.4 & 8.6 & 8.8 & 7.5 & 7.6 & 7.0 & 7.9 & 8.1 & 8.5 & 8.5 & 9.2 & 8.3 \\
\hline 20 & 12.5 & 9.3 & 9.0 & 9.4 & 7.8 & 8.2 & 7.8 & 7.9 & 8.4 & 8.7 & 8.5 & 8.2 & 8.6 \\
\hline 21 & 13.1 & 9.1 & 9.0 & 9.9 & 8.6 & 8.6 & 8.4 & 7.6 & 8.5 & 8.5 & 8.4 & 8.8 & 8.8 \\
\hline 22 & 12.1 & 8.3 & 9.1 & 9.6 & 8.7 & 8.6 & 8.9 & 8.2 & 8.4 & 8.3 & 8.3 & 9.6 & 8.9 \\
\hline 23 & 12.0 & 7.4 & 9.0 & 9.6 & 8.7 & 8.5 & 8.6 & 8.0 & 8.1 & 8.8 & 8.3 & 9.7 & 8.8 \\
\hline 24 & 12.5 & 6.8 & 9.0 & 9.3 & 8.3 & 8.6 & 8.8 & 8.1 & 8.0 & 8.6 & 8.5 & 8.9 & 8.7 \\
\hline$-\ldots$ & - - - & - - - - & - - - & --- & --- & - - - & - - - & - - - & $-\ldots$ & - - - - & --- & --- & $+\ldots$ \\
\hline Mean & 12.3 & 7.3 & 8.9 & 8.7 & 8.0 & 7.2 & 7.3 & 7.4 & 7.9 & 8.3 & 7.9 & 9.1 & | 8.2 \\
\hline Good & Hours & & & & & & & & & & & & \\
\hline & 245 & 179 & 667 & 720 & 744 & 676 & 744 & 587 & 597 & 744 & 701 & 349 & \\
\hline is & $\mathrm{hg} \mathrm{Ho}$ & urs & & & & & & & & & & & \\
\hline & 499 & 493 & 77 & $\odot$ & $\odot$ & 44 & $\odot$ & 157 & 123 & $\odot$ & 19 & 395 & \\
\hline
\end{tabular}


MEAN HOURLY WIND SPEEDS

FOXRIDGE SD

HAINES 5OM WIND SPEED (CH1) (MPS)

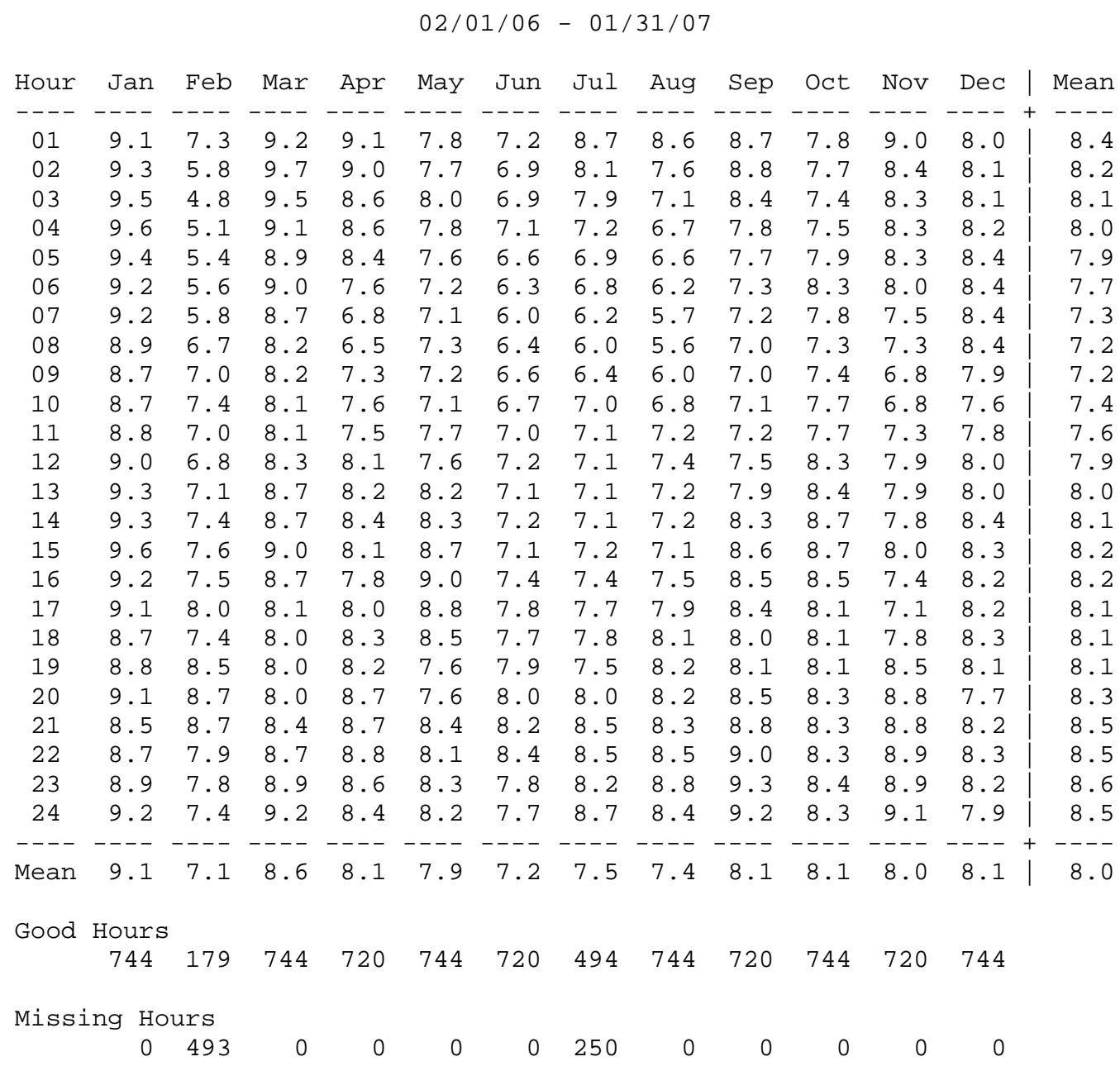

8,017 Hours of Good Data 743 Hours Missing 91.5\% Data Recovery 
MEAN HOURLY WIND SPEEDS

FOXRIDGE SD

INGALLS 5OM WIND SPEED ( $\mathrm{CH} 1)$ (MPS)

$02 / 01 / 06-01 / 31 / 07$

\begin{tabular}{|c|c|c|c|c|c|c|c|c|c|c|c|c|c|}
\hline Hour & Jan & Feb & Mar & Apr & May & Jun & Jul & Aug & Sep & oct & Nov & Dec & Mean \\
\hline - . & $-\ldots$ & . . - & - - - - & - - & $\ldots$ & - & - . & . - - & $\ldots$ & . - - & - & $\ldots$ & $\ldots$ \\
\hline 01 & 8.7 & 5.2 & 8.0 & 8.7 & 7.6 & 7.8 & 8.1 & 6.9 & 8.2 & 7.7 & 8.3 & 8.1 & 8.0 \\
\hline 02 & 8.5 & 4.6 & 8.3 & 8.9 & 7.3 & 7.5 & 7.8 & 6.4 & 8.2 & 7.7 & 8.3 & 8.0 & 7.8 \\
\hline 03 & 8.7 & 4.4 & 8.3 & 8.3 & 7.4 & 7.6 & 7.3 & 6.6 & 8.0 & 7.6 & 8.3 & 7.8 & 7.7 \\
\hline$\odot 4$ & 9.0 & 4.8 & 8.6 & 8.5 & 7.5 & 7.1 & 7.0 & 6.6 & 7.5 & 7.6 & 8.4 & 8.0 & 7.7 \\
\hline$\odot 5$ & 8.8 & 4.8 & 8.8 & 8.3 & 7.4 & 7.2 & 6.9 & 6.4 & 7.4 & 8.0 & 8.4 & 8.1 & 7.7 \\
\hline 06 & 8.4 & 5.5 & 8.4 & 7.7 & 7.4 & 6.9 & 6.5 & 6.1 & 7.5 & 8.1 & 8.1 & 8.2 & 7.5 \\
\hline 07 & 8.5 & 5.2 & 8.1 & 7.1 & 7.0 & 6.7 & 6.1 & 5.8 & 7.8 & 8.1 & 7.5 & 8.0 & 7.3 \\
\hline$\odot 8$ & 8.4 & 5.5 & 8.1 & 7.1 & 7.3 & 6.8 & 6.2 & 6.0 & 7.6 & 8.0 & 7.1 & 8.2 & 7.3 \\
\hline 09 & 8.4 & 6.0 & 8.3 & 7.6 & 7.2 & 7.1 & 6.4 & 6.1 & 7.5 & 7.6 & 6.5 & 7.9 & 7.3 \\
\hline 10 & 8.2 & 6.9 & 8.3 & 7.8 & 7.2 & 6.9 & 6.3 & 6.8 & 7.4 & 8.0 & 6.7 & 7.9 & 7.4 \\
\hline 11 & 8.6 & 6.5 & 8.4 & 7.9 & 7.8 & 6.9 & 6.7 & 7.2 & 7.5 & 8.1 & 7.3 & 8.4 & 7.7 \\
\hline 12 & 9.1 & 6.5 & 8.3 & 7.9 & 7.7 & 6.8 & 6.8 & 7.4 & 7.6 & 8.2 & 7.8 & 8.4 & 7.8 \\
\hline 13 & 9.4 & 6.9 & 8.5 & 7.9 & 7.9 & 6.9 & 6.9 & 7.2 & 7.7 & 8.4 & 7.8 & 8.5 & 7.9 \\
\hline 14 & 9.3 & 6.3 & 8.6 & 8.2 & 8.1 & 6.8 & 6.8 & 7.1 & 8.3 & 8.5 & 7.3 & 8.5 & 7.9 \\
\hline 15 & 9.4 & 7.5 & 8.9 & 8.4 & 8.2 & 6.8 & 6.6 & 6.7 & 8.3 & 8.6 & 7.2 & 8.0 & 7.9 \\
\hline 16 & 8.5 & 7.7 & 8.7 & 8.1 & 8.4 & 7.1 & 6.4 & 7.4 & 8.4 & 8.5 & 6.9 & 7.9 & 7.9 \\
\hline 17 & 8.1 & 7.7 & 8.3 & 8.0 & 8.1 & 7.3 & 6.6 & 7.9 & 8.2 & 8.1 & 6.7 & 8.4 & 7.8 \\
\hline 18 & 8.3 & 7.9 & 7.9 & 8.4 & 8.1 & 7.4 & 6.8 & 8.0 & 7.7 & 8.2 & 7.4 & 8.4 & 7.9 \\
\hline 19 & 8.2 & 8.5 & $8 . \odot$ & 8.4 & 7.3 & 7.7 & 6.8 & 7.8 & 7.8 & 8.4 & 7.7 & 7.9 & 7.8 \\
\hline 20 & 8.1 & 8.1 & 8.1 & 9.0 & 7.5 & 8.3 & 7.3 & 7.9 & 8.2 & 8.5 & 7.8 & 7.9 & 8.1 \\
\hline 21 & 8.2 & 7.6 & 8.0 & 9.3 & 8.3 & 8.6 & 8.0 & 7.5 & 8.5 & 8.1 & 7.9 & 8.3 & 8.2 \\
\hline 22 & 8.2 & 7.1 & 7.7 & 9.4 & 7.8 & 8.5 & 8.5 & 7.5 & 8.6 & 7.9 & 7.7 & 8.4 & 8.2 \\
\hline 23 & 8.5 & 6.7 & 7.8 & 9.1 & 8.2 & 7.9 & 8.2 & 7.7 & 8.3 & 8.2 & 7.7 & 8.2 & 8.1 \\
\hline 24 & 8.6 & 5.7 & 7.9 & 8.6 & 7.8 & 8.1 & 8.3 & 7.6 & 8.2 & 8.3 & 8.2 & 7.9 & 8.1 \\
\hline- & - - - - & - & --- & - - - - & --- & . . & $\ldots$ & - & --- & - & --- & --- & - - - - \\
\hline Mean & 8.6 & 6.5 & 8.3 & 8.3 & 7.7 & 7.4 & 7.1 & 7.0 & 7.9 & 8.1 & 7.6 & 8.1 & 7.8 \\
\hline \multirow[t]{2}{*}{ Good } & Hours & & & & & & & & & & & & \\
\hline & 744 & 178 & 744 & 720 & 744 & 720 & 744 & 744 & 720 & 744 & 720 & 724 & \\
\hline
\end{tabular}

Missing Hours

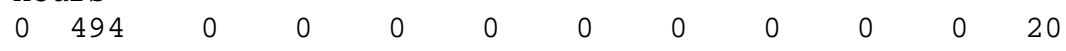

8,246 Hours of Good Data 514 Hours Missing $94.1 \%$ Data Recovery 


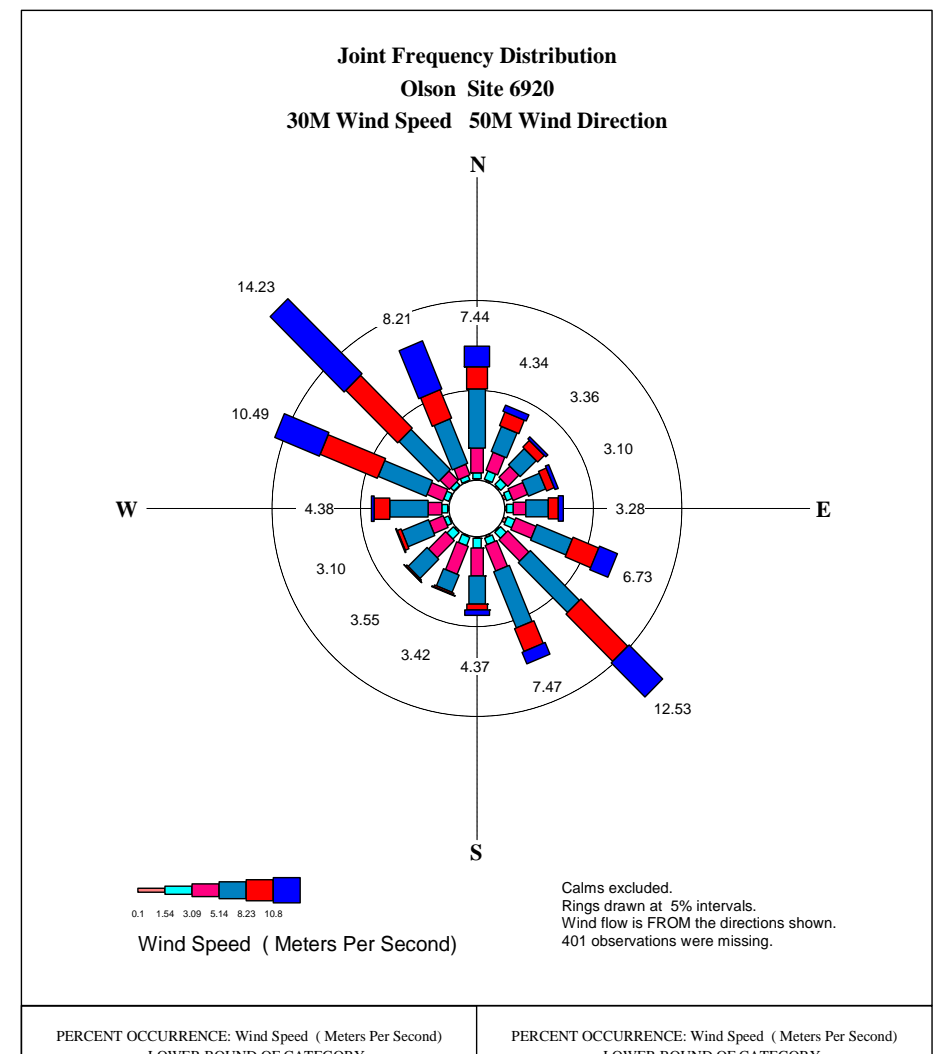

Fox Ridge, on the advice of Mr. Osborn, installed two additional MET towers in late 2010. Two NRG 60m Symphonie Systems were installed. These towers are used to correlate long term wind data with the data collected through the state's anemometer loan program. The data has correlated well.

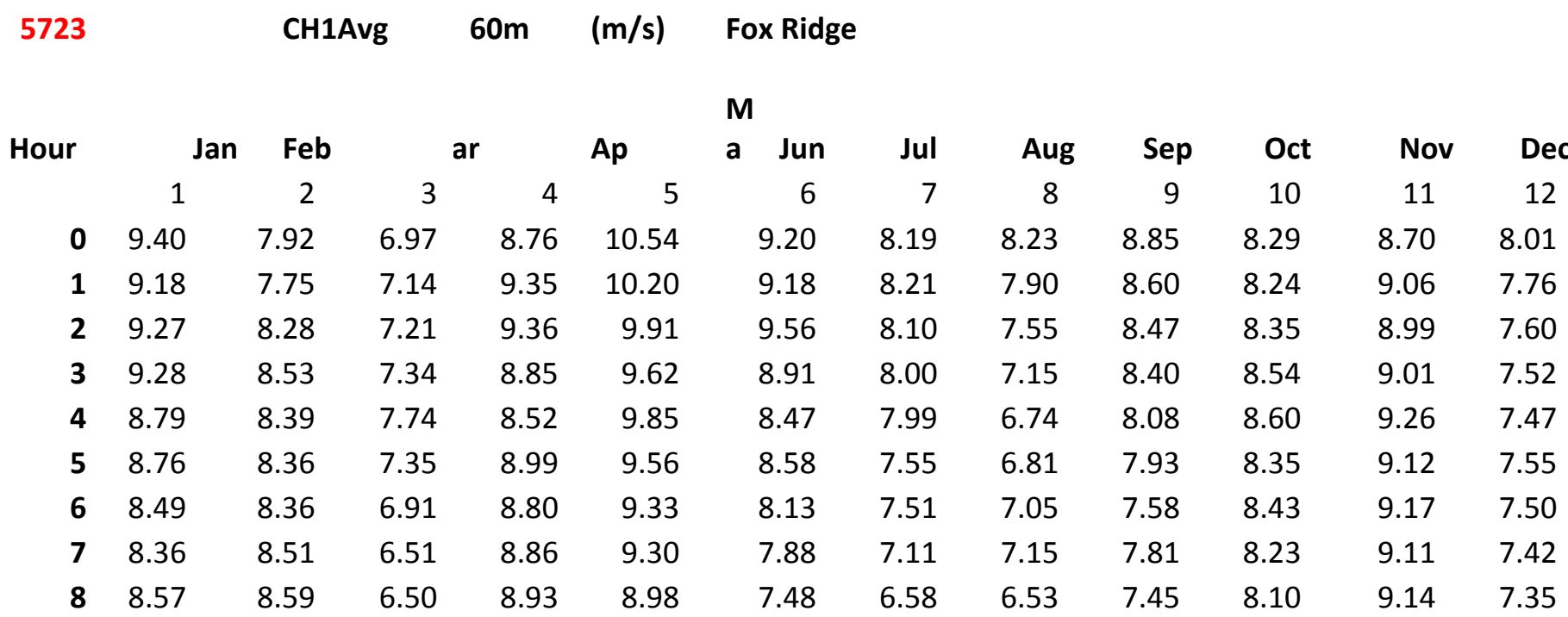




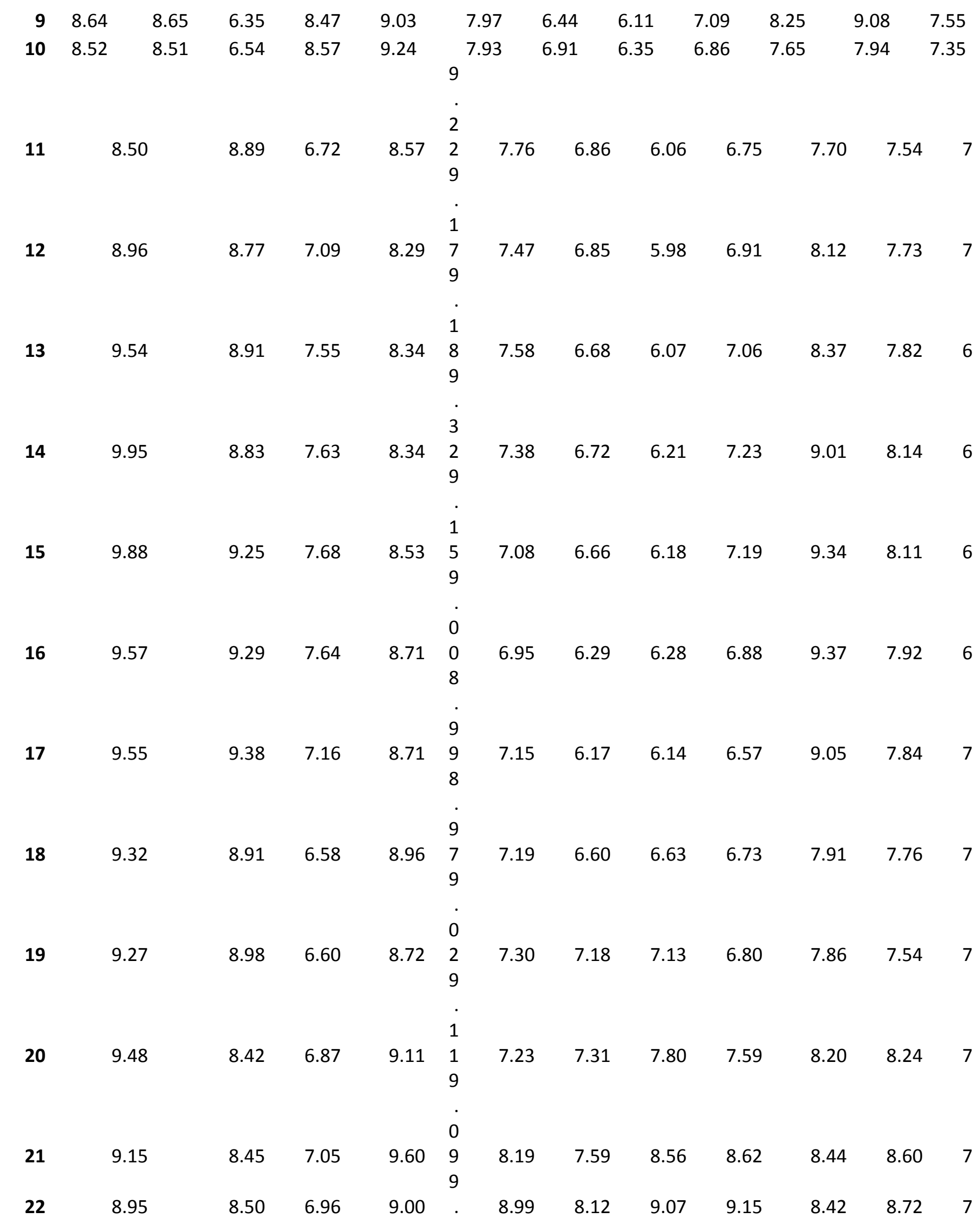




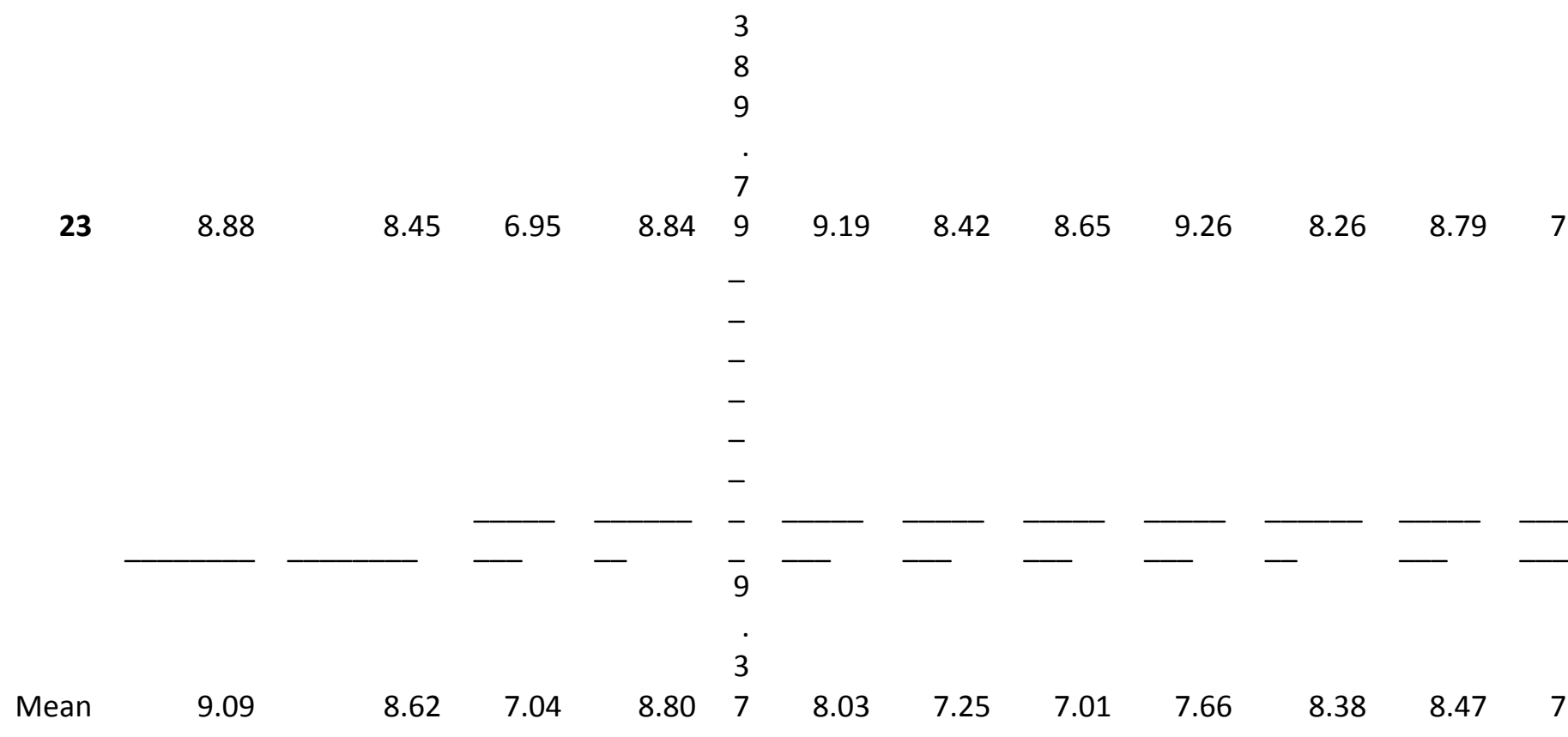

E. F. McCarthy \& Associates prepared a Wind Resource Assessment Report in August 2010. The net capacity factor is forecast to be $46.42 \%$ when using a Vestas V-90 1.8 MW wind turbine. Mr. McCarthy is a certified meteorologist with a history of over 25 years. His cumulative success rate exceeds $95 \%$ of his projected output.

Land Control: Fox Ridge, with the assistance of Disgen has entered into long-term land agreements with the landowners in the project area. The agreements allow for an Initial Period to allow for wind studies, permitting and financing of the project. In addition, the land agreements provide Fox Ridge the rights to, (i) conduct the studies, (ii) build own and operate the facility and (iii) transmit energy from the project. This Operational Period has a term of 35 years, with certain rights to extend.

Transmission Availability: The project area is immediately adjacent to the Western Maurine Substation. Maurine has $230 \mathrm{kV}, 115 \mathrm{kV}$ and $69 \mathrm{kV}$ service available which makes it a very convenient location for an expanding wind energy project. Western has confirmed that the project would be subject to the Federal Energy Regulatory Commission Large Generator Interconnection Policy. This policy requires a series of studies including (i) a feasibility study, (ii) a systems impact study and (iii) a facilities upgrade study. The System Impact Study has been completed. There were no unusual upgrade costs identified in the System Impact Study. 

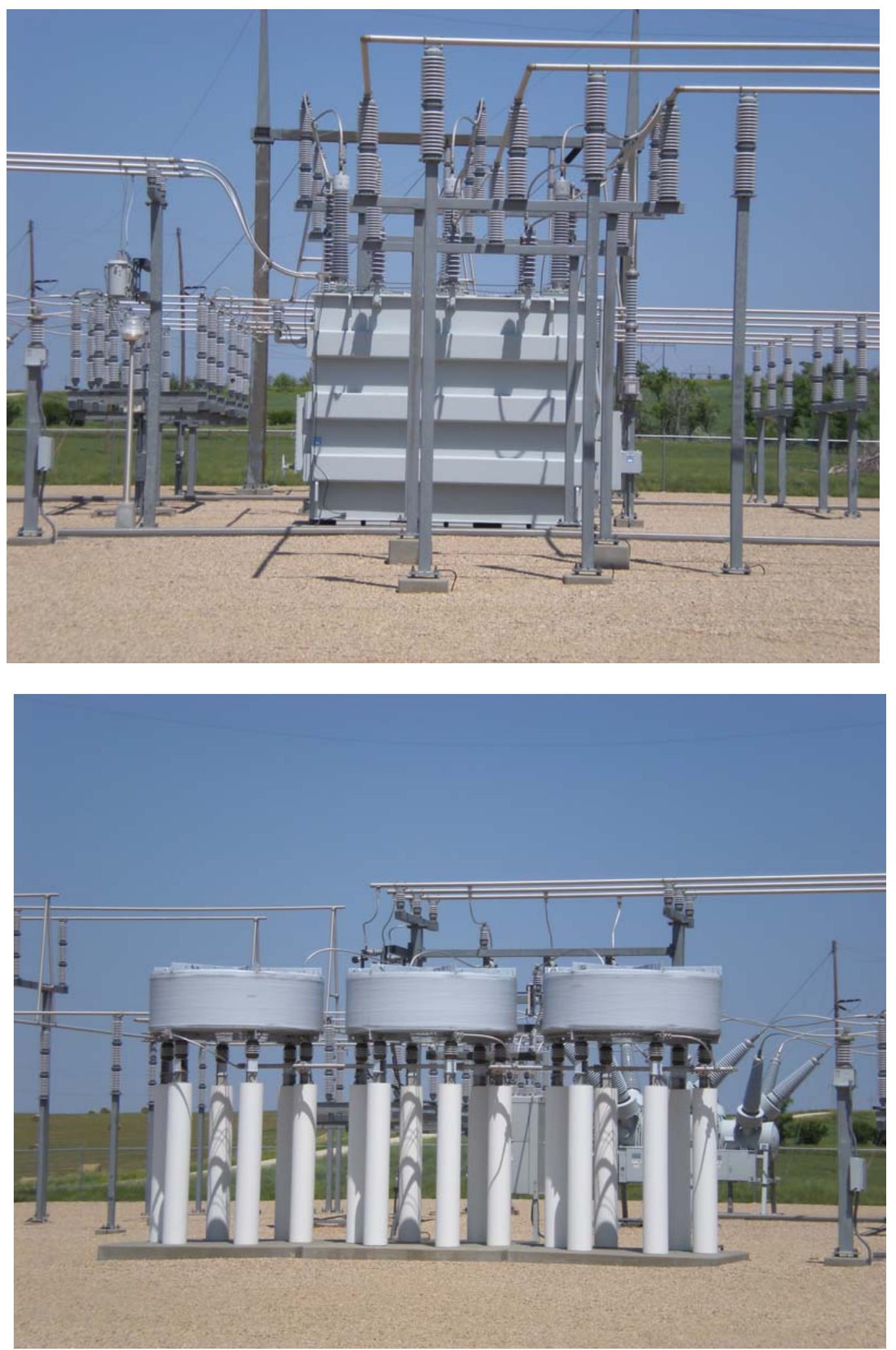

Western Area Power Administration Maurine Substation Equipment 
In March 2009, Excel Engineering conducted a Wind Energy Addition Feasibility Study for Fox Ridge. The study concluded that an additional $132 \mathrm{MW}$ could be interconnected at the Maurine substation. The study and the report are available.

In 2010, WAPA conducted a System Impact Study under an Interconnection Application filed by Fox Ridge for 120MW of installed wind capacity. The results showed that the interconnection capacity is sufficient, but raised issues concerning the deliverability of the energy to the population centers to the east. Consequently, Fox Ridge chose not to fund further studies until a level of transmission service could be defined. This decision terminates the application with WAPA and further such studies will need to be restarted

Fox Ridge accepted Disgen's recommendation of contracting with PWR Solutions in Dallas, Texas to conduct a transmission service analysis on possible delivery points to the east. PWR Solutions completed the first phase of the study in February 2012. The study evaluated the estimated costs to delivery $120 \mathrm{~mW}$ of energy from Maurine to load sinks to the east. Below is the load sink map. 


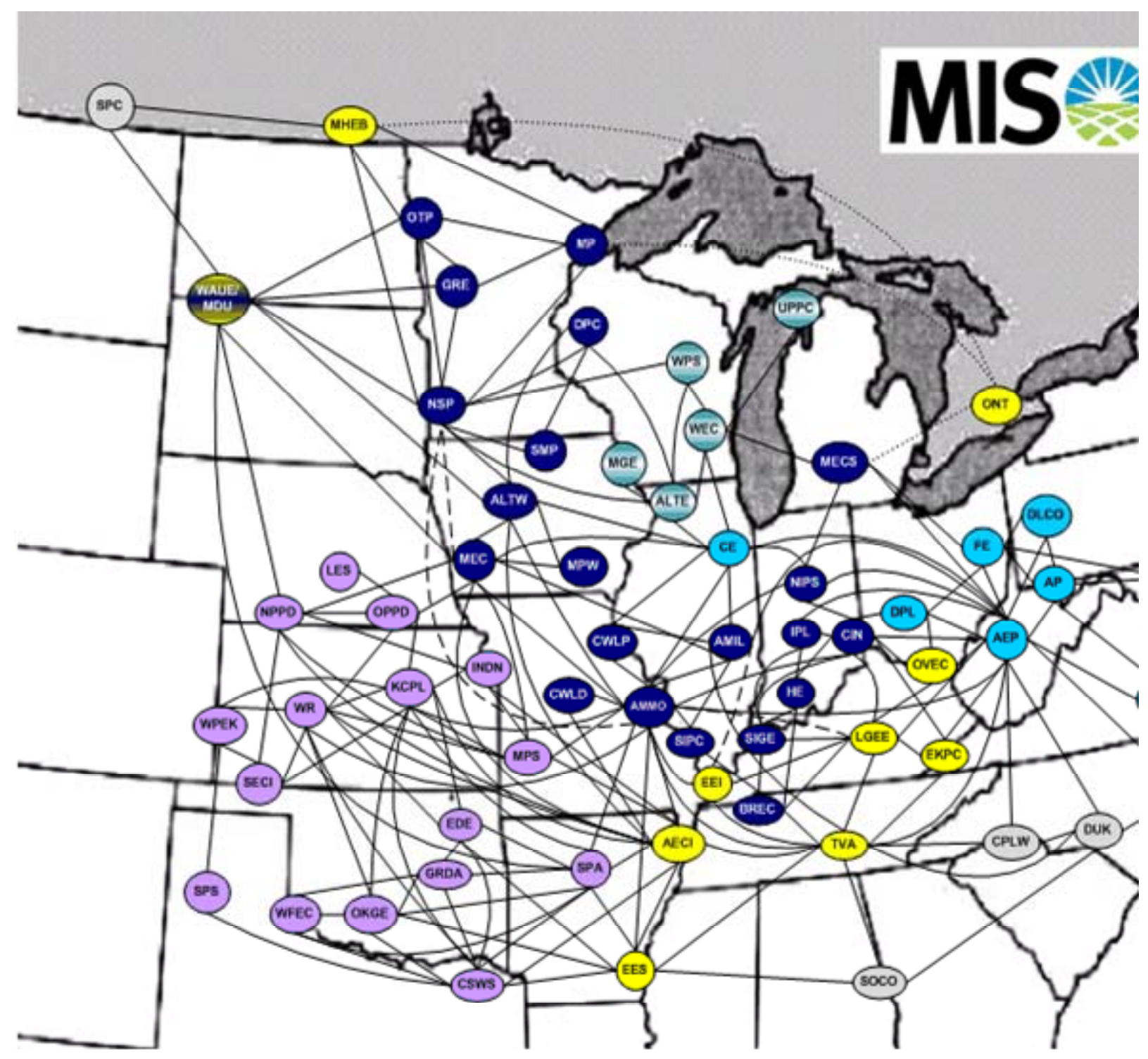

PWR Solutions determined the optimum load sink is the MISO MEC Balancing Authority in Southwestern Iowa. PWR Solutions estimated that the transmission system upgrade incremental cost to deliver from Maurine (WAPA/MDU Balancing Authority) to MEC would be approximately $\$ 10$ million. For a 120MW, $\$ 200$ million, wind facility this is a small increment to the transmission system. Disgen's preliminary conclusion is that the Fox Ridge 120MW wind facility can deliver energy into MISO at MEC at a competitive price currently offered in MISO. This conclusion assumes wheeling fees for WAPA and for MEC and line losses associated with the recommended $230 \mathrm{kV}$ interconnection and transmission system.

Disgen requested PWR Solutions to examine an alternative project size of 200MW and the result yielded an estimated transmission system upgrade cost that exceeded the project's economic ability to absorb. This incremental analysis confirms that under existing conditions the $120 \mathrm{MW}$ is near optimal. 
Environmental Permitting: The interconnection to the Western substation at Maurine creates the potential of a federal nexus resulting in permitting requirements established under NEPA. As the project is expected to be about 50 average megawatts, Western authorizes such permitting to be accomplished under an EA. Disgen recommended to Fox Ridge that an initial "Preliminary Environmental Assessment" be completed to define the potentially sensitive issues. The preliminary assessment was completed by Western EcoSystems Technologies (West) of Bismarck, South Dakota and no fatal flaws were identified. From this assessment, West created a set of studies, including bat monitoring, consistent with the requirements of the US Fish and Wildlife Service (FWS). The studies have been completed, with reports, and a pre-construction consultation with the US Fish and Wildlife Service (USFWS). The Western NEPA Compliance Officer has provided estimated budgets for a formal Western Environmental Assessment.

In addition, an historical and archeological review must be performed to document any such recorded sites. The South Dakota State Historical Preservation Officer (SHPO) will be the source of any recorded sites. This data becomes a key component of the EA document. Disgen has located an experienced firm (Quality Services) in Rapid City that has agreed to conduct the studies. Field investigation on site will be required prior to construction.

Land Use Permitting: The Meade County Seat is Sturgis SD. The county enacted a "Wind Generator Ordinance 32" on 8-13-2008. The ordinance is not onerous for unincorporated Meade County. "A Wind Generator Facility or Meteorological Tower shall be considered a Permitted Use is approved by the Meade County Governing Board with proper documentation required by this Ordinance.” The timing of such a permit will be approximately 90 days. The county permit requirements are quite limited and no issues are expected. The Public Utility Commission Permitting process is much more exhaustive and time consuming.

Public Utility Commission Permitting: The State of South Dakota Public Utilities Commission (PUC) has jurisdiction over any energy generator greater the 100MW. Consequently, an application for Fox Ridge will be required with the PUC. Integral to this application will be a project description that includes the details of the environmental permitting, addressing the state and federal issues; particularly of the US Fish \&Wildlife Service. The application is not complicated, but must be complete when filed or significant delays may occur. Disgen has relationships with each of the agencies and has the capability, in conjunction with West, to complete the application. Disgen has been provided an example of a completed and approved application which is in the public domain. Unfortunately, the PUC requires a public hearing in the community where the project is based. The commissioners' schedules are difficult to coordinate and this meeting can easily become the critical path.

TransCanada Pipeline: TransCanada is in process of upgrading its system with a new pipeline segment called Keystone. The pipeline is planned to bisect the wind project area of Fox Ridge. Fox Ridge has been working cooperatively with TransCanada and there 
are no known conflicts between the wind project and the pipeline. The pipeline has requested the locations of construction and operational roads in order to expand the wall thickness of the pipeline. Fox Ridge has responded with a preliminary site plan which follows:

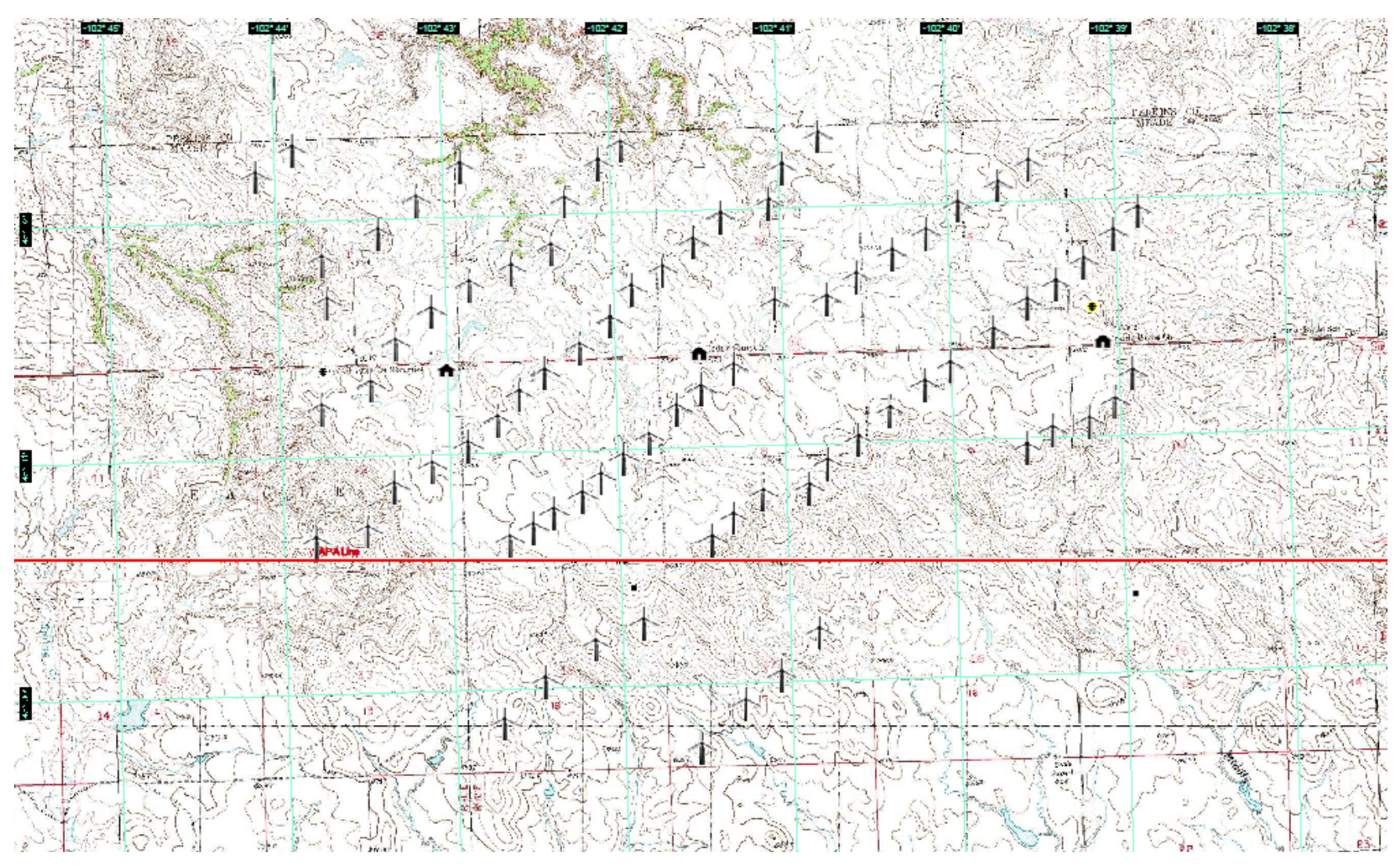

Power Sales: Western is chartered with marketing the electricity produced by the federal hydro facilities along the Missouri River Pick-Sloan System. Further, Western is statutorily authorized to purchase additional electricity on the spot market to supplement electricity when the hydro system falls short. Customarily, Western purchases fossil fuel based electricity for supplemental power, but has indicated it would be willing to consider acting as an agent for its customers in purchasing wind energy from projects such as Fox Ridge. In order to avoid incremental transmission costs (wheeling charges) it is most cost effective to sell energy directly to Western or Network Customers of Western in the Upper Great Plains Region. A list of those customers is supplied in Exhibit "A".

Western has explained that Basin Electric Cooperative and Montana Dakota Utilities have independent delivery points at the Maurine substation. Basin has indicated that it is possible to wheel through its system to reach the population serving utilities in Minnesota. Fox Ridge is contracting with HDR to conduct a preliminary optimum delivery route for wheeling from Maurine to a MISO Interconnect Point. Given the wind 
resource of Fox Ridge, Osborn believes that the delivered cost of energy to MISO will be superior to wind projects developed within the MISO system.

Financing: It is the goal of the Fox Ridge Team to fully develop the wind facility under a limited liability company and sell that entity to a third party. However, Fox Ridge recognizes that additional development capital will be required to complete the project. These additional costs will be geo-technical studies, additional environmental studies and, importantly, transmission studies. Consequently, Fox Ridge is willing to consider joint development partners or a sale of the assets. Any fees recognized by Fox Ridge are planned for to be dedicated to the capital cost of a new school. Further, Fox Ridge may be able to retain an annual development royalty which may be allocated to the operational expense of the school.

The economics of the project and the power purchase prices are dependent on the actions of congress as they relate to tax credits for renewables; wind energy specifically. Currently a 2.2 cent per kilowatt hour Production Tax Credit (PTC) is available for any wind energy project placed in service by year end 2012. The PTC applies for the first ten years of operation and is increased based on inflation as determine by the US DOE. The PTC was originally enacted by congress in the Energy Policy Act of 1992. Congress has allowed the PTC to expire a number of times; only to extend it again and again while applying it retroactively to projects installed during the interim period. While the PTC is scheduled to expire at the end of 2012, both sides of the aisle in Congress appear to support its extension in some form. Legislation has been introduced in the House to extend the PTC by four additional years. GE recently released a report that shows the PTC is a self-funding credit.

The project will likely be financed as a "non-recourse project financing”. The principal owner must be able to fully utilize the PTC in order to achieve an acceptable cost of energy for the buyer. The financing will include a significant fee to Fox Ridge as the developer. This amount could conservatively be $\$ 12$ million if Fox Ridge completes development and the project is "shovel ready"; an amount that contributes greatly to an enhanced school facility. The Fox Ridge Team has an excellent chance of achieving this goal depending on the ability of the transmission capacity to accept and deliver the energy to a qualified and credit worthy buyer.

Equity will be placed with an entity that can fully utilize the PTC or other tax credits the Congress provides in future legislation.

Project Pro-forma: Disgen has created a preliminary non-recourse financing project proforma assuming all equity without including the benefits of the federal loan guarantees. The model is available to interested parties that sign a Non Disclosure Document with Fox Ridge. The PTC is included and the assumption is that Congress will extend the PTC availability for four years.

Development Schedule: Fox Ridge has completed the wind studies and a Wind Assessment Report sufficient for financing. A set of preliminary project economics has 
been created for the $120 \mathrm{MW}$ project referenced above. The System Impact Study Report has been released by Western. A Facilities Upgrade Study has been deferred until a transmission delivery path is identified. Fox Ridge contracted with PWR Solutions of Dallas Texas for the analysis of the transmission service upgrade requirements. The environmental study protocols will be negotiated with the Western NEPA Compliance Office and will be deferred until such time as additional study funds become available. There are no significant impacts are expected. The significant unknowns are the environmental studies and their review by the consulting agencies. The full development should be able to be completed in about one year's time. The financing schedule will be heavily dependent upon the behavior of Congress relative to the extension of the PTC.

Summary: The Fox Ridge 120MW wind facility has sufficient wind resource to be an economically viable wind facility. There are no known environmental barriers to construction. Quality road access is supplied with US 212; which runs through the project area. A Western transmission line bisects the project area although capacity on this line requires more formal and detailed studies. The key to the financing of the project lies in the PPA which has not been proposed to any utility. As with all commercial wind facilities, the issues are transmission capacity and a financeable power purchase agreement.

Relative to the transmission availability, the System Impact Study indicated that there are several constraints in the lines between Maurine and the MISO grid. PWR Solutions studies referenced above have assuaged many of these concerns.

\section{The Serviceable Market for Fox Ridge Wind Power}

Background: Throughout the United States, wind energy has grown exponentially during the past thirteen years to over $40,000 \mathrm{MW}$ of installed capacity at yearend 2010 . For the most part, this growth is a result of regulatory and legislative mandates rather than the vigorous embrace of the utility industry. Many state legislatures have adopted Renewable Portfolio Standards (RPS) where regulated utilities are required to include in their portfolios a defined amount of renewable energy as a percentage of total energy sold. Thirty-five states and the District of Columbia have RPS rules. Typically these rules exempt rural electric cooperatives and small municipal utilities; neither of which is a regulated entity. Consequently, the large Investor Owned Utilities (IOUs) are the primary focus of these RPS rules. In some states like Texas, Colorado and Minnesota, utilities have seen these rules as an opportunity for incremental profits; while in other states the utilities have vigorously opposed such rules. Each state has adopted slightly different rules. This has created some ambiguity for utilities that serve multiple states.

North Dakota and South Dakota do not have RPS rules. These states are primarily served by unregulated utilities, Basin Electric and Western Area Power Administration (WAPA), a federal agency not subject to state regulations. A small portion of western South Dakota is served by the IOU Black Hills Power and Light. The major market for 
RPS based electricity is further east into the Midwest Independent System Operator (MISO) in Minnesota and Iowa. Black Hills and points further west are in a separate reliability councils called the Western Electric Coordinating Company (WECC). The analysis shows that little, if any, transmission capacity is available to move energy west. Therefore, Fox Ridge believes the best approach to a power purchase agreement (PPA) is engage the utilities within MISO; specifically Xcel, Mid America Energy and Minnesota Power. Otter Tail and MDU remain candidates, but are relatively small and may not be able to accept 120MW of wind on their systems.

In order to serve MISO utilities, the energy must be transferred across WAPA lines for which there is a tariff. The tariff is defined as "Wheeling Fees" and is published. Generally, the wheeling fee will create a toll of approximately 1.5 cents per Kwh. This fee is called "postage stamp" which means it does not matter how far the energy is moved, the fee is fixed. Fox Ridge is located is a different coordinating council from MISO. Therefore to deliver to MISO, the energy must be wheeled through the WAPA System at a cost of about 1.5 cents.

Economically, this works simply because the wind resource in western South Dakota is far superior to the wind resource in MISO. So superior that the cost of energy produced by Fox Ridge will be lower than that produced in MISO by more than the 1.5 cent cost to wheel. This has been discussed with Mid America and the utility will entertain a proposal.

In MISO, the utilities are signing long-term PPAs with a starting price at about $\$ 50$ per Mwhr escalating at 2\% to 2.5\% annually for a period of 20-25 years. Fox Ridge will be able to compete in this market, provided the wheeling and system upgrade costs are consistent with the studies provided by PWR Solutions.

\section{Next Steps}

The Fox Ridge 120MW Wind Facility is a viable economic and commercial project. The owning entity is in need of an infusion of capital to complete the development. The key cost components to be funded are; (i) the WAPA NEPA Compliance effort, the formal transmission studies to interconnect to the Maurine WAPA Substation, (iii) the formal transmission service studies to be completed by WAPA and MISO and (iv) the location of a power purchaser. In order to obtain the development capital necessary to complete the project, Disgen is assisting Fox Ridge in identifying and presenting the project opportunity to a number of prospective purchasers. By far, the key item required for financing is the PPA with a creditworthy utility. With the permission of Fox Ridge, Disgen has been in discussions with several utilities in MISO, Xcel not included, about a PPA from the Fox Ridge Facility. There is interest in this project, but until the transmission and final Cost of Energy issues are resolved, the prospective energy buyers are reluctant to enter into negotiations. 
There are two interested potential partners for Fox Ridge. One is currently completing due diligence and the other will start due diligence proceedings in March. Once the economics are fully understood, it is expected that one of these entities will propose a purchase of the Fox Ridge wind project. 


\section{Exhibit A \\ Western Network Customers}

\begin{tabular}{|c|c|c|c|}
\hline \multicolumn{4}{|c|}{ Municipals by State } \\
\hline lowa & Minnesota & Nebraska & North Dakota \\
\hline Akron & $\underline{A d a}$ & Ansley & Cavalier \\
\hline Alta & Adrian & Arnold & Grafton \\
\hline Alton & Alexandria & Auburn & Hillsboro \\
\hline Anita & Barnesville & Beatrice & Hope \\
\hline Anthon & Benson & Beaver City & Lakota \\
\hline Atlantic & Breckenridge & Blue Hill & Maddock \\
\hline Auburn & Detroit Lakes & Broken Bow & Northwood \\
\hline Aurelia & East Grand Forks & Burwell & $\underline{\text { Park River }}$ \\
\hline$\underline{\text { Breda }}$ & Elbow Lake & Callaway & Riverdale \\
\hline Coon Rapids & Fairfax & Cambridge & Sharon \\
\hline Corning & Fairmont & $\underline{\text { Crete }}$ & $\underline{\text { Stanton }}$ \\
\hline Denison & Fosston & $\underline{\text { Curtis }}$ & Valley City \\
\hline Estherville & Granite Falls & David City & 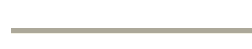 \\
\hline Fonda & Halstad & Deshler & South Dakota \\
\hline Fontanelle & Hawley & DeWitt & \\
\hline Glidden & Henning & Emerson & Aberdeen \\
\hline Graettinger & Lackson & Fairbury & Arlington \\
\hline Harlan & Kandiyohi & $\underline{\text { Franklin }}$ & Aurora \\
\hline Hartley & Lake Park & Fremont & Badger \\
\hline Hawarden & $\underline{\text { Lakefield }}$ & Grand I sland & Beresford \\
\hline Hinton & Litchfield & $\underline{\text { Hastings }}$ & Big Stone City \\
\hline Kimballton & Luverne & Indianola & Brookings \\
\hline Lake Park & Madison & Laurel & Bryant \\
\hline Lake View & Marshall & Lincoln & Burke \\
\hline Laurens & Melrose & Lyons & Colman \\
\hline Lenox & Moorhead & Madison & Estelline \\
\hline Manilla & Mountain Lake & Nebraska City & Faith \\
\hline Manning & Newfolden & Neligh & Flandreau \\
\hline Mapleton & Nielsville & Ord & Fort Pierre \\
\hline Marathon & $\underline{\text { Olivia }}$ & Oxford & Groton \\
\hline Milford & $\underline{\text { Ortonville }}$ & Pender & Hecla \\
\hline Neola & $\underline{\text { Redwood Falls }}$ & Pierce & Howard \\
\hline Onawa & $\underline{\text { Sauk Center }}$ & Plainview & Langford \\
\hline Orange City & Shelly & Randolph & Madison \\
\hline
\end{tabular}




\begin{tabular}{|c|c|c|c|}
\hline Paullina & Sleepy Eye & $\underline{\text { Red Cloud }}$ & McLaughlin \\
\hline Pochahontas & Springfield & $\underline{\text { Sargent }}$ & Miller \\
\hline Primghar & St. James & Schuyler & Parker \\
\hline Remsen & Staples & Shickley & Pickstown \\
\hline Rock Rapids & Stephen & South Sioux City & Pierre \\
\hline Sanborn & Thief River Falls & Spalding & $\underline{\text { Plankinton }}$ \\
\hline$\underline{\text { Sergeant Bluff }}$ & Tyler & Spencer & $\underline{\text { Sioux Falls }}$ \\
\hline Shelby & $\underline{\text { Wadena }}$ & $\underline{\text { Stuart }}$ & Tyndall \\
\hline Sibley & Warren & $\underline{\text { Syracuse }}$ & $\underline{\text { Vermillion }}$ \\
\hline$\underline{\text { Sioux Center }}$ & Westbrook & $\underline{\text { Tecumseh }}$ & $\underline{\text { Volga }}$ \\
\hline Spencer & $\underline{\text { Willmar }}$ & $\underline{\text { Waho }}$ & Watertown \\
\hline$\underline{\text { Stanton }}$ & Windom & $\underline{\text { Wakefield }}$ & Wessington \\
\hline Villisca & Worthington & Wayne & $\underline{\text { Springs }}$ \\
\hline Wall Lake & & West Point & White \\
\hline \multirow[t]{4}{*}{ Woodbine } & & Wilber & Winner \\
\hline & & $\underline{\text { Winside }}$ & \\
\hline & & Wisner & \\
\hline & & Wood River & \\
\hline
\end{tabular}

\section{Rural Electric Cooperatives}

Agralite Electric Cooperative Basin Electric Power Cooperative Big Horn County Electric Cooperative, Inc. Brown County Rural Electrical Association Capital Electric Cooperative, Inc. Central I owa Power Cooperative Central Montana Electric Power Cooperative Central Power Electric Cooperative, Inc. Corn Belt Power Cooperative East River Electric Power Cooperative Federated Rural Electric Association Grand Electric Cooperative, Inc. Itasca-Mantrap Cooperative Services Kandiyohi Power Cooperative KEM Electric Cooperative, Inc. $\underline{L Q O}$ Power Cooperative Lake Region Electric Cooperative McLeod Cooperative Power Meeker Cooperative L\&P Association Minnesota Valley Cooperative L\&P Association Minnkota Power Cooperative, Inc. Mor-Gran-Sou Electric Cooperative

Nobles Cooperative Electric Northern Electric Cooperative Northwest lowa Power Cooperative Oliver-Mercer Electric Cooperative, Inc. Redwood Electric Cooperative Rosebud Electric Cooperative, Inc. Runestone Electric Association 
Rushmore Electric Power Cooperative, Inc.

South Central Electric Association

Southern Montana Electric G\&T Cooperative, Inc.

Stearns Electric Association

Todd-Wadena Electric Cooperative

Upper Missouri G\&T Electric Cooperative

\section{Federal Customers}

Bureau of Reclamation (Mni Wiconi project)

Ellsworth AFB, South Dakota

Turtle Mountain \& Fort Totten, North Dakota

\section{Public Power Districts}

Municipal Energy Agency of Nebraska, Falls City

Nebraska Public Power District

Omaha Public Power District

\section{Rural Water Users}

Dickey Rural Water Project, North Dakota

Garrison Rural Water Association, North Dakota

Mclean Sheridan Rural Water Board, North Dakota

Mid-Dakota Rural Water System, Inc.

Missouri Rural Water Association

Mni Wiconi

South Central Regional Water District, Burleigh, North Dakota

Southwest Water Authority, North Dakota Legislature

\section{Western I rrigation}

Garrison Diversion, North Dakota

Hammond Irrigation District, Montana

Hysham Irrigation District, Helena, Montana

Loup Basin Reclamation District, Nebraska

Praire County Water \& Sewer District \#2, Montana

Turtle Mountain \& Fort Totten, North Dakota 